\title{
The Use of Complementary and Alternative Medicine Among Patients with Chronic Lung Disease
}

\author{
Kronik Akciğer Hastalığına Sahip Hastalar Arasında Tamamlayıcı ve Alternatif Tıp Kullanımı
}

\author{
Hasan Oguz Kapicibasi', Erhan Akinci² \\ ${ }^{1}$ Department of Thoracic Surgery; ${ }^{2}$ Department of Psychiatry, Canakkale Onsekiz Mart University, Faculty of Medicine, \\ Canakkale, Turkey
}

\begin{abstract}
Aim: The aim of this study is to investigate the behaviors related to and the factors affecting complementary and alternative medicine (CAM) use in patients with chronic lung diseases, such as lung cancer and chronic obstructive pulmonary disease (COPD).
\end{abstract}

Material and Method: A total of 60 patients with lung cancer and COPD were enrolled in the study. The data were collected by a form of demographic and clinical characteristics, the State-Trait Anxiety Inventory (STAI), and the Eysenck Personality Questionnaire Revised-Abbreviated Form (EPQR-A).

Results: The most commonly used CAM method was the combination of phytotherapy and apitherapy, accounting for $48.3 \%$ $(n=29)$ of the patients. $48.8 \%(n=22)$, to whom the CAM method was administered, used the combination at least once a month. The most common cause for the use of CAM method was cough. No statistically significant relationship was observed between the dependent variable - the decision of CAM use - and the independent variables sociodemographic characteristics, disease type, and the scores from STAI and EPQR-A. On the other hand, the EPQR-A psychoticism subscale was found to be a significant and independent predictor of the CAM users' views of benefit $(\beta=0.354, p=0.029$ ).

Conclusion: Our study suggests that the most commonly used CAM method was the combination of phytotherapy and apitherapy. It was understood that psychoticism, one of the personality traits, may be a significant factor affecting the CAM users' views of benefit.

Key words: chronic disease; phytotherapy; lung cancer; complementary therapies; alternative medicine

\section{ÖZET}

Amaç: Bu çalıșmanın amacl, akciğer kanseri ve kronik obstrüktif akciğer hastalığı (KOAH) gibi kronik akciğer hastalığı olan hastalarda tamamlayıcı ve alternatif tıp (TAT) kullanımıyla ilgili davranıșları ve bunu etkileyen etmenleri araștırmaktır.
Materyal ve Metot: Çalıșmaya akciğer kanseri ve KOAH'lı olmak üzere toplam 60 hasta alındı. Demografik ve klinik özelliklere yönelik bilgi formu, Durumluk-Sürekli Kaygı Envanteri (STAl) ve Eysenck Kișilik Anketi Gözden Geçirilmiș/Kısaltılmıș Formu (EKA-GGK) kullanılarak veriler toplandı.

Bulgular: En sık kullanılan TAT yöntemi fitoterapi ve apiterapinin \%48,3 ( $n=29)$ birlikte kullanımıydı. TAT yöntemi kullananların \%48,8'inin (n=22) ayda en az bir kez kullanım öyküsü vardı. TAT kullanımının en sık nedeni öksürüktü. TAT kullanım kararı ile demografik özellikler, hastalık tipi, STAl ve EKA-GGK ölçek bağımsız değișkenleri arasında istatistiksel olarak anlamlı bir ilișki bulunmadı. Öte yandan, EKA-GGK psikotisizm alt ölçeğinin TAT kullanımından fayda görme inancında anlamlı ve bağımsız bir belirteç olduğu görüldü ( $\beta=0,354, p=0,029)$.

Sonuç: Çalıșmamızda fitoterapi ve apiterapinin birlikte kullanımının, en sık kullanılan TAT yöntemi olduğu görüldü. TAT kullanımından fayda görme inancında psikotisizm kișilik özelliğinin belirleyici bir etmen olabileceği anlașılmaktadır.

Anahtar kelimeler: kronik hastalık; fitoterapi; akciğer kanseri; tamamlayıcı tedaviler; alternatif tip

\section{Introduction}

The main reasons why patients prefer complementary and alternative medicine (CAM) are chronic diseases, inadequate treatments of conventional medicine, and therefore patients' dissatisfaction ${ }^{1,2}$. Studies report that CAM is widely used in chronic diseases such as cancer, stroke, diabetes, heart diseases, and chronic obstructive pulmonary disease $(\mathrm{COPD})^{3}$. Lung cancer is the leading cause of cancer-induced death worldwide ${ }^{4,5}$. The most frequent incidences of lung cancer in Turkey

IIetișim/Contact: Hasan Oguz Kapicibasi, Canakkale Onsekiz Mart University, Faculty of Medicine, Department of Thoracic Surgery, Canakkale, Turkey • Tel: 05323779907 • E-mail: turcica@hotmail.com • Geliș/Received: 09.05.2020 • Kabul/Accepted:01.08.2020

ORCID: Hasan Oğuz Kapıcıbaşı, 0000-0001-7275-1039 • Erhan Akıncı, 0000-0003-3331-8165 
were observed in males (45.2 per 100.000) followed by females $(7.5 \text { per } 100.000)^{6}$. COPD is a chronic health problem with increasing frequency. It leads to high morbidity and mortality ${ }^{7}$. In the literature, COPD patients have been shown to seek different treatment methods to solve problems such as muscle weakness, decreased exercise capacity, endocrine system disorders, increased lung infection rates, anxiety, and depression $^{8}$. There is not much evidence of the role of CAM in the treatment of these diseases ${ }^{9}$. Resorting to CAM has considerably increased in the industrialized Western countries in the last 25 years. It is applied in a multitude of areas, such as aromatherapy, acupuncture, homeopathy, anthropozoic medicine, herbal remedies, kinesiology, massage, naturopathy, shiatsu, traditional Chinese medicine, and yoga ${ }^{10-12}$. Except for praying, the most commonly used CAM interventions are herbal remedies, chiropractic, and homeopathy ${ }^{13}$. The use of CAM varies across countries, i. e. accounting for 48.2\% in Australia, $42.1 \%$ in the United States, 70\% in Canada, $49.3 \%$ in France, $70 \%$ in China, and 80\% in African countries ${ }^{14}$. Although the number of CAMrelated studies are insufficient in Turkey, Kav et al. report that the frequency of CAM use in cancer patients ranges from $22.1 \%$ to $84.1 \%{ }^{15}$. It can be inferred from this data that CAM methods are preferred more frequently by patients with chronic diseases such as lung cancer and COPD in our society and easier to use compared to conventional medical treatment as perceived by these patients. This can make patients more prone to abuse by people without proper medical training which may lead to unwanted incidences. In this study, we aimed to investigate the behaviors related to and factors affecting CAM in patients with chronic lung diseases, such as lung cancer and COPD.

\section{Material and Method}

\section{Sample}

Our study is descriptive and cross-sectional and was conducted at the Canakkale Onsekiz Mart University Health Application and Research Hospital. The sample consisted of two different groups of inpatients and outpatients with lung cancer and COPD. Thirty patients from each group were included in the study. Only the patients having volunteered to participate in the study, having the adequate level of mental competence to fill out the forms in the study and having given written consent to participate in the study. The research approval was obtained from the local ethics committee (October 31, 2018, Decision no: 2018-19).

\section{Data Collection Tools}

National Institutes of Health (NIH) refers to CAM as "a group of diverse medical and health care systems, practices, and products that are not presently considered to be part of conventional medicine" and the National Center for Complementary and Alternative Medicine (NCCAM) places the CAM methods in five categories.

I. Alternative whole medical systems (homeopathic and naturopathic, Chinese, and Ayurvedic medicine)

II. Manipulative and body-based methods (chiropractic and osteopathic manipulation, massage)

III. Biologically based therapies (herbs, foods, vitamins and other dietary supplements, including natural products such as shark cartilage)

IV. Mind-body interventions (meditation, prayer, mental healing, art, music, and dance therapy)

V. Energy therapies (qi gong, Reiki, therapeutic touch, and electromagnetic field exposure $)^{16}$.

The data were collected with the questionnaire built on these parameters.

Sociodemographic and Clinical Data Form: It is a tool developed by the researchers to obtain sociodemographic and clinical data for the purposes of the study. It also incorporates an evaluation form intended to learn survey the patients' CAM experiences and the relevant data.

State-Trait Anxiety Inventory (STAI): It was used to assess the participating patients' anxiety levels in the study. The inventory was translated into Turkish and then the translation's validity and reliability were investigated. The scale consists of two different subscales to measure state anxiety and trait anxiety, each of which consists of 20 items. The state anxiety subscale (STAI-I) measures the level of anxiety in a particular situation. The trait anxiety subscale (STAI-II) measures the anxiety experienced on a daily basis as independent of the individual's situation. The scores on both scales ranged from 20 to 80 High scores indicate high anxiety levels, whereas low scores indicate low anxiety levels ${ }^{17,18}$.

Eysenck Personality Questionnaire Revised-Abbreviated (EPQR-A): The scale is a 24-item shortened version of the Eysenck Personality Questionnaire RevisedAbbreviated (EPQR-A 48), designed to measure the three factors posited by Eysenck: Neuroticism (N), Extraversion (E), Psychoticism (P), and validity with 
one subscale (deception). Each subscale contained six items, and the participants were expected to respond each item as Yes (1) or No (0). The range of the points for each personality trait is from 0 to 6 . The validity and reliability of the scales' Turkish translations study were assessed by Karanci et al. ${ }^{19,20}$.

\section{Statistical Analysis}

The obtained data were analyzed with SPSS 22.0 (SPSS Inc., Chicago, IL, USA), a statistical software program. The numerical variables were expressed as mean \pm standard deviation (SD) and median and the categorical variables as percentage (\%). Whether the variables were normally distributed or not was tested by the Kolmogorov-Smirnov test. In the study, the Student's t-test was used for the analysis of the continuous variables that satisfied the assumptions of parametric tests and the Mann-Whitney $U$ test was used for the analysis of the continuous variables that did not meet the assumptions of parametric tests. Chi-square test was used for group-based comparisons of the categorical variables. Linear regression (enter model) was employed to analyze the independent variables that might impact the dependent variable of CAM use. The probability values less than 0.05 were considered statistically significant.

\section{Results}

$16.7 \%(n=10)$ of the participants were female and $83.3 \%(n=50)$ were male. The participants ranged between 24 and 87 years of age and the mean age was calculated to be $63.2 \pm 15.8$ years. $76.7 \%(n=46)$ of the patients were married, while $23.3 \%(n=14)$ were single, widowed, or divorced. $71.7 \%(n=43), 11.7 \%(n=7)$, and $6.7 \%(n=4)$ of the participants were elementary school, high school, university graduates, respectively, whereas $10 \%(n=6)$ were illiterate (Table 1$)$.

$75 \%(n=45)$ of the participants had a history of CAM use and $71.1 \%(n=32)$ stated that they derived substantial benefit from the treatment (Table 2).

The most commonly employed CAM method was the combination of phytotherapy and apitherapy with $48.3 \%(n=29) .28 .8 \%(n=13)$ of those who availed of a CAM method, used it once a week and $48.8 \%(n=22)$ once a month. The common causes of CAM use were listed as coughs by $66.6 \%(n=30)$, supplementing primary treatment by $33.3 \%(n=15)$, general weakness by $33.3 \%(n=15)$, and weight loss by $31.1 \%(n=14)$.
In their decision to use the CAM methods, 11 patients (18.3\%), 6 patients (10\%), 4 patients (6.7\%) stated that their friends, families, media played a decisive role, respectively. 4 (6.7\%) expressed it was their own decision. No statistically significant difference was detected between the COPD and lung cancer groups in terms of the frequency of the CAM use and its benefits $(\mathrm{p}>0.05)$.

The analyses yielded no statistically significant relationship between the CAM use (dependent variable) and the independent variables, i. e. sociodemographic characteristics, disease type, and score from the STAI and EPQ $(p>0.05)$. On the other hand, the factors influential in the level of benefiting were analyzed by linear regression. In the analyses, the level of benefiting was operationalized as independent variable, while gender, age, education, income, STAI-I, STAIII, EPQ-N, EPQ-E, and EPQ-P as dependent variables. A significant positive linear correlation was observed between EPQ psychoticism subscale and the CAM users' views of benefit $(\beta=0.354, p=0.029)$ (Table 3).

Table 1. Sociodemographic characteristics of the participants

\begin{tabular}{llcc}
\hline Variables & & Mean $(\mathrm{n})$ & $\mathrm{SD} / \%$ \\
\hline Age (years) & & 63.2 & 15.8 \\
Gender & Female & 10 & 16.7 \\
& Male & 50 & 83.3 \\
Marital status & Married & 46 & 76.7 \\
& Single & 3 & 4.9 \\
& Widowed/divorced & 11 & 18.1 \\
Education & Illiterate & 6 & 10 \\
& Elementary school & 43 & 71.7 \\
& High school & 7 & 11.7 \\
& University & 4 & 6.7 \\
\hline
\end{tabular}

SD, standard deviation

Table 2. Participants' CAM use and views of benefit

\begin{tabular}{llcc}
\hline Variables & & $\mathrm{N}$ & $(\%)$ \\
\hline CAM use & No & 15 & 25 \\
& Yes & 45 & 75 \\
Views of benefit & Unsatisfied (0 points) & 13 & 28.9 \\
& Slightly satisfied (1 point) & 17 & 37.8 \\
& Very satisfied (2 points) & 12 & 26.7 \\
& Extremely satisfied (3 points) & 3 & 6.7 \\
\hline
\end{tabular}


Table 3. Factors independently affecting CAM users' views of benefit

\begin{tabular}{lcccccc}
\hline \multirow{2}{*}{$\begin{array}{l}\text { Independent } \\
\text { variables }\end{array}$} & $\mathrm{B}(\mathrm{S} . \mathrm{E})$. & $\beta$ & $\mathrm{p}$ & Lower & Upper \\
\cline { 5 - 7 } Constant & $0.362(1.298)$ & & & & \\
Gender & $0.82(0.424)$ & 0.033 & 0.847 & -0.779 & 0.943 \\
Age & $0.211(0.125)$ & 0.285 & 0.101 & -0.043 & 0.464 \\
Education & $-0.007(0.170)$ & -0.007 & 0.969 & -0.352 & 0.338 \\
Income & $0.242(0.269)$ & 0.159 & 0.374 & -0.303 & 0.787 \\
STAI-I & $-0.003(0.18)$ & -0.037 & 0.864 & -0.039 & 0.033 \\
STAI-II & $-0.023(0.023)$ & -0.212 & 0.332 & -0.070 & 0.024 \\
EPQ-N & $-0.041(0.090)$ & -0.077 & 0.656 & -0.224 & 0.143 \\
EPQ-E & $0.046(0.077)$ & 0.127 & 0.553 & -0.110 & 0.203 \\
EPQ-P & $0.300(0.132)$ & 0.354 & 0.029 & 0.032 & 0.567 \\
\hline
\end{tabular}

STAl, state-trait anxiety inventory; $\beta$, standardized coefficient; EPQ-N/E/P, Eysenck personality questionnaire (neuroticism, extroversion, psychoticism subscales). EPQ subscales, STAl, age, education, gender, and income independent variables were analyzed with linear regression (Enter) and the most suitable model was used.

\section{Discussion}

In our study, the rates of CAM use were high. The most common reason was cough and the most frequently used method was the combination of phytotherapy and apitherapy. Although most of the patients having recourse to the CAM methods stated that they substantially benefited from the treatment, the psychotic personality traits of these patients were found to be decisive in this result. CAM use is very common in many chronic lung diseases, especially in lung cancer, and its use continues to increase. Three quarters of the patients in our study were found to employ at least one CAM method actively supplementary to conventional medical treatments. Generally, patients resort to CAM to support their primary medical treatment or to reduce side effects thereof. Moreover, a desire to find a working remedy for their chronic diseases may also lead patients to use $\mathrm{CAM}^{21,22}$. The usage and duration of these applications may vary according to the clinical condition of the patient. Baron et al. report an increase in CAM use as the duration and severity of the disease increase ${ }^{23}$. In the literature, among the commonly used CAM applications in the occurrence of chronic lung diseases are herbal products, breathing techniques, steam applications, massage, prayer, and preach ${ }^{24,25}$ and it is known that individuals' interest and thoughts concerning CAM practices are affected by various psychosocial factors ${ }^{26,27}$. In our study, it was found that the use of herbal products with honey was the most commonly preferred CAM method. The

reasons for the frequent use of herbal products and apitherapy are the influence of visual and print media, their being considered safe and natural, relatively easy access to them, and their widespread use in society.

The related literature reports that the most common source of information about CAM is friends or neighbors $(38.6 \%)^{28,29}$. It is stated that patients generally receive information about CAM applications from media and they are also affected by the previous experiences of family members and other people in their social network $^{30,31}$. The present study revealed that friends were the most common factor in resolving to use CAM, while media and family too were listed as important influencers. It was observed that patients resorted to these applications based on the information obtained from media and their friends and/or family member with no proper education. In our study, although their personality or anxiety levels were found not to be correlated with the decision to use CAM, it was realized that the psychotic personality traits might have a determining role in the CAM users' views of benefit. Although individuals' perceived benefit from CAM is subjective, patients' treatment motivation, their expectations from treatment, patients' reality testing and perception manner may affect its efficacy ${ }^{32,33}$.

Eysenck's personality theory states that there are three biologically based traits of temperament: psychoticism, extraversion, and neuroticism. According to Eysenck, individuals display different levels of each trait, which are what make our personality ${ }^{2034}$. The described personality traits are related to certain emotions and behaviors. Psychoticism is the third personality trait in the Eysenck's personality theory and the level of psychoticism reflects their vulnerability to tough-mindedness, impulsiveness, hostility, and nonconformity. This trait also includes some unusual, bizarre thoughts and perceptions ${ }^{35,36}$. In this study, the patients with high scores of psychoticism were observed to have more positive ideas about the benefits from CAM use than the others did. Thus, these findings may indicate that individuals with psychoticism traits can be described to be toughminded and/or have distorted perceptions of reality.

This study has several limitations worth noting. The most obvious limitation in this research was the small sample size. Furthermore, the fact that EPQR-A's subscale of psychoticism has a lower internal consistency compared to the other subscales due to the concerns over its reliability and validity as studied in Turkey, which should be assessed as a limitation of our study. 
As a result, personality traits have a decisive role in our perception of events and decision-making. In the present study, it was found that COPD and lung cancer patients frequently used the CAM methods. The most commonly used CAM methods were herbal treatment and apitherapy. However, the patients were found not to be knowledgeable enough about CAM. This negative situation may make patients using CAM more prone to abuse or lead to adverse side effects. Therefore, health professionals should be able to guide CAM-using patients and manage their safety since CAM use is becoming a more common practice every day. In this regard, it is considered that health care providers should be educated about this phenomenon.

\section{References}

1. Harris PE, Cooper KL, Relton C, Thomas KJ. Prevalence of complementary and alternative medicine (CAM) use by the general population: a systematic review and update. Int J Clin Pract 2012;66(10):924-39.

2. Fischer FH, Lewith G, Witt CM, Linde K, von Ammon $\mathrm{K}$, Cardini $\mathrm{F}$ et al. High prevalence but limited evidence in complementary and alternative medicine: guidelines for future research. BMC Complement Altern Med 2014;14:46.

3. Şahin ZA, Şahin M. The view of patients with chronic obstructive pulmonary disease (COPD) on complementary and alternative medicine (CAM) in Eastern Turkey. African J Tradit Complement Altern Med 2013;10(4):116-21.

4. Jemal A, Bray F, Center MM, Ferlay J, Ward E, Forman D. Global cancer statistics. CA Cancer J Clin 2011;61(2):69-90.

5. Allemani C, Weir HK, Carreira H, Harewood R, Spika D, Wang X-S et al. Global surveillance of cancer survival 1995-2009: analysis of individual data for 25676887 patients from 279 population-based registries in 67 countries (CONCORD-2). Lancet 2015;385(9972):977-1010.

6. Türkiye Kanser İstatistikleri 2014 Yilı Türkiye Kanser İstatistikleri; https://hsgm. saglik. gov. tr/tr/kanseristatistikleri/yillar/2014-yili-turkiye-kanser-istatistikleri. html [accessed 1706 19].

7. Vestbo J, Hurd SS, Agustí AG, Jones PW, Vogelmeier C, Anzueto A et al. Global strategy for the diagnosis, management, and prevention of chronic obstructive pulmonary disease. Am J Respir Crit Care Med 2013;187(4):347-65.

8. Moy ML, Teylan M, Danilack VA, Gagnon DR, Garshick E. An Index of Daily Step Count and Systemic Inflammation Predicts Clinical Outcomes in Chronic Obstructive Pulmonary Disease. Ann Am Thorac Soc 2014;11(2):149-57.

9. Pauwels RA, Buist AS, Calverley PMA, Jenkins CR, Hurd SS. Global strategy for the diagnosis, management, and prevention of chronic obstructive pulmonary disease. Am J Respir Crit Care Med 2001;163(5):1256-76.
10. Eisenberg DM, Davis RB, Ettner SL, Appel S, Wilkey S, Van Rompay M, et al. Trends in alternative medicine use in the United States, 1990-1997. JAMA1998;280(18):1569.

11. Bücker B, Groenewold M, Schoefer Y, Schäfer T. The use of complementary alternative medicine (CAM) in 1001 German adults: results of a population-based telephone survey. Gesundheitswesen 2008;70(8-9): e29-36.

12. Bodeker G, Ong CK, Grundy C, Burford G, Shein K. WHO Global Atlas of Traditional, Complementary and Alternative Medicine: Text and Map Volumes. Kobe: World Health Organization, the WHO Centre for Health Development; Pck edition, 2005.

13. Frass M, Strassl RP, Friehs H, Müllner M, Kundi M, Kaye AD et al. Use and acceptance of complementary and alternative medicine among the general population and medical personnel: A systematic review. Ochsner Journal 2012;12(1):45-56.

14. Özçelik G, Toprak D. Bitkisel tedavi neden tercih ediliyor? Ankara Med J 2015;15(2):48-58.

15. Tas F, Ustuner Z, Can G, Eralp Y, Camlica H, Basaran M et al. The prevalence and determinants of the use of complementary and alternative medicine in adult Turkish cancer patients. Acta Oncol 2005;44(2):161-7.

16. National Center for Complementary and Alternative Medicine (NCCAM). The Use of Complementary and Alternative Medicine in the United States Bethesda, Md: National Institutes of Health; December 2008.

17. Spielberger CD. Manual for the State-Trait Anxiety Inventory (STAI). Palo Alto, CA. Consulting Psychologists Press; 1983.

18. Öner N, Le Compte A. Durumluk-Sürekli Kayg1 Envanteri El Kitabı. İstanbul: Boğaziçi Üniversitesi Yayınları; 1983:1-26.

19. Francis LJ, Brown LB, Philipchalk R. The development of an abbreviated form of the revised Eysenck Personality Questionnaire (Epqr-A): Its use among students. Personality and Individual Differences 1992;13(4):443-9.

20. Karancı AN, Dirik G, Yorulmaz O. Turkish Adaptation of Eysenck Personality Questionnaire Revised-Abbreviated. Turkish Journal of Psychiatry 2007;18(3):254-61.

21. Çakmak S, Nural N. Kronik hastalıklarda tamamlayıcı ve alternatif tedavi uygulamaları. Turkiye Klinikleri J Intern Med Nurs-Special Topics 2017;3(2):57-64.

22. Molassiotis A, Panteli V, Patiraki E, Ozden G, Platin N, Madsen $\mathrm{E}$, et al. Complementary and alternative medicine use in lung cancer patients in eight European countries. Complement Ther Clin Pract 2006;12(1):34-9.

23. Baron SE, Goodwin RG, Nicolau N, Blackford S, Goulden V. Use of complementary medicine among outpatients with dermatologic conditions within Yorkshire and South Wales, United Kingdom. J Am Acad Dermatol 2005;52(4):589-94.

24. Akinci AC, Zengin N, Yildiz H, Sener E, Gunaydin B. The complementary and alternative medicine use among asthma and chronic obstructive pulmonary disease patients in the southern region of Turkey. Int J Nurs Pract 2011;17(6):571-82. 
25. Sidora-Arcoleo K, Yoos HL, Kitzman H, Mcmullen A, Anson E. Don't ask, don't tell: parental nondisclosure of complementary and alternative medicine and over-the-counter medication use in children's asthma management. J Pediatr Health Care 2008;22(4):221-9.

26. Sirois FM, Gick ML. An investigation of the health beliefs and motivations of complementary medicine clients. Soc Sci Med2002;55(6):1025-37.

27. Wagner PJ, Jester D, LeClair B, Taylor AT, Woodward L, Lambert J. Taking the edge off: why patients choose St. John's Wort. J Fam Pract 1999;48(8):615-9.

28. Durusoy Ç, Güleç AT, Durukan E, Bakar C. Dermatoloji polikliniğine başvuran akne vulgaris ve melasma hastalarında tamamlayıcı ve alternatif tıp kullanımı: anket çalışması. Dermatol 2010;4:14-7.

29. Eisenberg DM, Kessler RC, Van Rompay MI, Kaptchuk TJ, Wilkey SA, Appel S et al. Perceptions about complementary therapies relative to conventional therapies among adults who use both: results from a national survey. Ann Intern Med 2001;135(5):344.

30. Palinkas LA, Kabongo ML. The use of complementary and alternative medicine by primary care patients. A Surf*Net Study. J Fam Pract2000;49(12):1121-30.
31. Begbie SD, Kerestes ZL, Bell DR. Patterns of alternative medicine use by cancer patients. Med J Aust 1996;165(10):545-8.

32. Owens JE, Taylor AG, Degood D. Complementary and alternative medicine and psychologic factors: Toward an individual differences model of complementary and alternative medicine use and outcomes. J Altern Complement Med 1999;5(6):529-41.

33. Honda K, Jacobson JS. Use of complementary and alternative medicine among United States adults: The influences of personality, coping strategies, and social support. Prev Med (Baltim)2005;40(1):46-53.

34. Bech P. How to measure the personality. Personality and Disease, Christoffer Johansen (Ed.), London: Academic Press, 2018, pp:17-32.

35. Ashton MC. Personality Disorders. Individual Differences and Personality, Michael C. Ashton (Ed.), Third Edition, London: Academic Press, 2018, Pages 179-97.

36. Knežević G, Lazarević L. B, Purić D, Bosnjak M, Teovanović P, Petrović Bet al. Does Eysenck's personality model capture psychosis-proneness? Asystematic review and meta-analysis. Personality and Individual Differences 2019;143:155-164. 